\title{
Building a Maturity \& Capability Model Repository
}

\author{
Christiane Gresse von \\ Wangenheim \\ Department of Informatics and Statistics \\ Federal University of Santa Catarina \\ Florianópolis, Brazil \\ +55-48-3721-9516 \\ gresse@incod.ufsc.br \\ Fergal McCaffery \\ Lero \& the RSRG \\ Dundalk Institute of Technology \\ Ireland \\ +353-42-9370462

\section{Fergal.McCaffery@dkit.ie}

\begin{abstract}
A complicated and time-consuming phase in the development of Maturity/Capability Models (MCMs) is the identification of existing relevant source models as, currently, information on existing MCMs is provided in very different forms and levels of detail on diverse web sites, publications etc. In this paper, we present our ongoing research on developing a web-based repository to store and provide overview information on MCMs as a continuous knowledge management effort maintained within the Software Process Improvement (SPI) community. Such a centralized repository containing metadata on MCMs is expected to facilitate the identification of relevant models (as well as parts) and provide a systematic basis for the development/evolution or customization of MCMs.
\end{abstract}

\section{Categories and Subject Descriptors}

D.2 [Software Engineering]: Software Management; H.3 [Information Storage and Retrieval]

\section{General Terms}

Management, Standardization.

\section{Keywords}

Software Process Improvement, Maturity/Capability models, Content Management, Knowledge Management.

\section{INTRODUCTION}

Process improvement and assessment guided by a maturity level or a process capability profile based on a capability/maturity model is now well established in practice as a successful means

Permission to make digital or hard copies of all or part of this work for personal or classroom use is granted without fee provided that copies are not made or distributed for profit or commercial advantage and that copies bear this notice and the full citation on the first page. To copy otherwise, or republish, to post on servers or to redistribute to lists, requires prior specific permission and/or a fee.

PROFES 2011, June 20-22, 2011, Torre Canne, Bari, Italy.

Copyright 2011 ACM 1-58113-000-0/00/0010...\$10.00.

\section{Luigi Buglione}

\author{
ETS / Engineering.IT SpA \\ Rome, Italy \\ $+39-06.8307 .4472$ \\ luigi.buglione@eng.it
}

Ronny F. Vieira da Cruz

Department of Informatics and Statistics Federal University of Santa Catarina

Florianópolis, Brazil

+55-48-3721-9516

ronny.ufsc@gmail.com for improving the software process. In this context, we define MCMs as models describing best practices for software life cycle processes, based on good engineering and process management principles, and with a set of process attributes comprising the capability/maturity aspects, suitable for the purpose of assessing and/or improving processes [1]. Examples are the CMMI-DEV (Capability Maturity Model Integration for Development) model [2] or the, ISO/IEC 15504-5 exemplar ISO/IEC Process Assessment Model for Software Engineering [3], ITIL [4], etc. These models are used as an evaluative and comparative basis for process improvement and/or assessment assuming that higher process capability or organizational maturity is associated with better performance.

Therefore, a multitude of process capability/maturity models and standards have been developed on international, national and domain/sector specific levels to address particular disciplines or business needs[5][6][7]. Yet, models and standards that define software engineering processes are still progressing in terms of the breadth and depth of their coverage, their viewpoint and the maturity of the standards themselves [8].

Currently, we can observe various trends regarding the evolution of capability/maturity models. Existing models are being evolved, creating new versions of generic models, such as, the models of the CMMI framework and ISO/IEC 15504-5 on a periodic basis. Yet, as the range of software sectors and domains is wide, there are also several initiatives underway to develop domain or sector specific pre-defined models, as in general, the adaptation of generic models is not an easy process, as the standards' tailoring rules aren't always consistent or detailed sufficiently [8]. Examples, include, Spice4Space [9] and AutomotiveSPICE [10] or Medi SPICE [11], as well as harmonization initiatives, such as Enterprise SPICE [12], which aims to integrate more than 30 existing models for the enterprise context.

The development of MCMs for a specific domain is a time consuming process as related models have to be first identified and then compared in terms of structure and content. Likewise, much effort is required when harmonizing various existing models 
into one model either through modeling effort or when aligning software processes within several other models (in parallel).

Yet, before taking any action, you need to know which existing models contain relevant information - covering (at least partially) the domain of focus, as either a full process, a process step, or a process element (normative or informative). For instance, which models exist that focus on small and medium enterprises? Or, which models in the Software \& Systems Engineering domain include a 'Knowledge Management' process? So where do you find relevant models? Currently process engineers do this mostly based on their individual knowledge of popular models and/or performing literature or internet searches. This often leads to the simple adoption of one reference model, possibly overlooking more adequate models or alternatives, because they are not sufficiently aware of alternative solutions from other models. It is currently quite difficult to obtain information on existing models - especially in relation to overview information on models that is required to make decisions as to whether to adopt a specific model. What is missing is a uniform characterization scheme for such models and an online repository where such information can be browsed or accessed via advanced searches using the characterization scheme.

Yet, currently there does not exist any centralized repository with such kind of information. In this respect only online navigation based browsers exist, which present information with respect to a specific model, such as e.g. the CMMI Browser [19], but which do not provide information on different models.

Thus, in order to provide a wide overview on existing MCMs, we describe in this paper our ongoing research on developing a web-based repository to store and provide overview information on MCMs as a continuous knowledge management effort maintained within the SPI community.

\section{Modeling a MCM Repository}

A core element of our research on the development of MCMs [13] is the 'Maturity \& Capability Models' (MCM) repository. The MCM represents a Knowledge Management System [14] for managing information on MCMs supporting the storage and access of information on MCMs. Its basic objective is to provide enhanced search and browsing capabilities based upon a process engineer's needs, and to assist them to better understand the information and knowledge available by presenting it in an easily recognizable format.

The MCM is a web-based repository that enables the storage, discovery and retrieval of information on MCMs offering the following operations:

1. Search/find - the ability to locate MCMs through simple and advanced searches via different kind of MCM attributes (such, as domain as well as through specific processes).

2. Browsing - the ability to browse a taxonomy of MCMs.

3. Gather Model's Metadata - the ability to allow a model author to include/modify/exclude meta information on a MCM.

4. Comment - the ability to comment on a specific MCM.

The idea for the operationalization of such a repository is based on a model of a network of Communities of Practice (CoPs) [15] linked loosely by a central body and whose elements are shared through an online space. In this context, model authors can register information on MCMs and model users or researchers can access the information via the web (Figure 1).

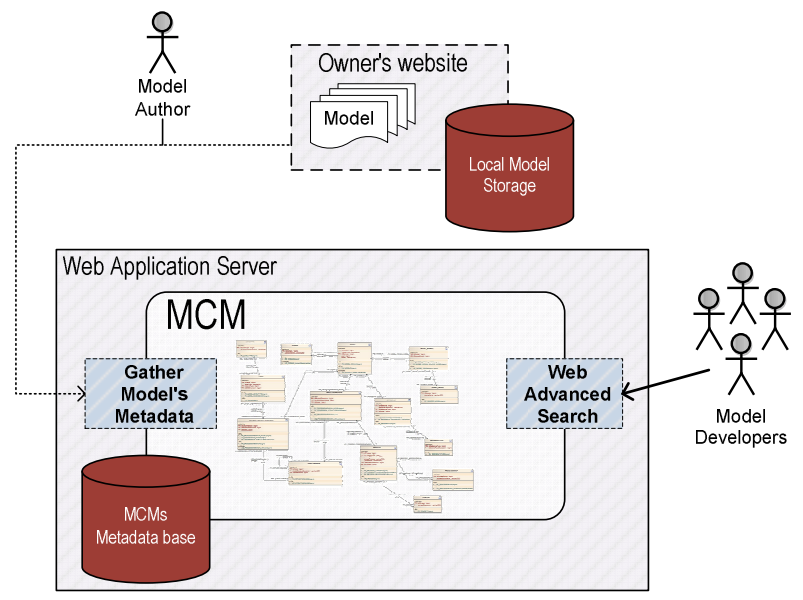

Figure 1 - Schematic representation of the repository architecture

Within the repository, MCMs are represented through metadata, whereas the actual models reside either on the owner's website or at a designated location. Metadata ("data about data") are descriptive labels used to index content for use, such as artefact management, discovery and delivery. Therefore, relating to information about the object - as opposed to the object itself. Metadata provides descriptions of the format and attributes of the object - MCMs. Metadata systems make the process of retrieving content more efficient and effective [16].

Storing and managing metadata instead of the actual artefact also facilitates dealing with rights and ownership as well as interoperability. Therefore, through analyzing relevant information on MCMs, we defined a set of metadata that enabled the characterization of MCMs in the repository through their main dimensions and attributes (e.g. number and list of its processes, process groups, maturity levels, etc...). (Table 1).

Table 1. Metadata definition

\begin{tabular}{|c|c|c|}
\hline Metadata & Description & Example \\
\hline Id & $\begin{array}{l}\text { Sequential unique } \\
\text { identification }\end{array}$ & $\mathrm{m} 01$ \\
\hline Acronym & $\begin{array}{l}\text { Acronym of the } \\
\text { SPCMM }\end{array}$ & Automotive SPICE \\
\hline Name & Name of the model & $\begin{array}{l}\text { Automotive SPICE } \\
\text { Assessment Model }\end{array}$ \\
\hline Description & $\begin{array}{l}\text { A brief description } \\
\text { on the model }\end{array}$ & $\begin{array}{l}\text { Process Assessment Model } \\
\text { developed by consensus of the } \\
\text { car manufacturers within the } \\
\text { Automotive Special Interest } \\
\text { Group (SIG) of the joint } \\
\text { Procurement Forum/SPICE User } \\
\text { Group under the Automotive } \\
\text { SPICE® initiative }\end{array}$ \\
\hline $\begin{array}{l}\text { Version } \\
\text { number }\end{array}$ & $\begin{array}{l}\text { Version number of } \\
\text { the SPCMM }\end{array}$ & PRM 4.5; PAM 2.5 \\
\hline $\begin{array}{l}\text { Year of } \\
\text { publication }\end{array}$ & $\begin{array}{lr}\text { year } & \text { of } \\
\text { publication of the }\end{array}$ & 2010 \\
\hline
\end{tabular}




\begin{tabular}{|c|c|c|}
\hline & $\begin{array}{l}\text { respective version } \\
\text { of the } S P C M M\end{array}$ & \\
\hline Owner & $\begin{array}{l}\text { Owner/ institution } \\
\text { of origin of the } \\
\text { SPCMM }\end{array}$ & The SPICE User Group \\
\hline $\begin{array}{l}\text { Main } \\
\text { reference(s) }\end{array}$ & $\begin{array}{l}\text { reference(s) for } \\
\text { the publication } \\
\text { and/or web site } \\
\text { where it is } \\
\text { described }\end{array}$ & $\begin{array}{lrr}\text { The SPICE } & \text { User } & \text { Group. } \\
\text { "Automotive } & \text { SPICE® } & \text { Process } \\
\text { Reference } & \text { Model } & \text { v4.5," } \\
\text { Technical Report, 2010. } & \end{array}$ \\
\hline Link & $\begin{array}{l}\text { web site where } \\
\text { detailed } \\
\text { information on the } \\
\text { SPCMM is } \\
\text { available online }\end{array}$ & http://www.automotivespice.com \\
\hline Domain & $\begin{array}{l}\text { classifying a MM } \\
\text { according to the } \\
\text { domain for which } \\
\text { it was developed } \\
\text { (e.g. Medical } \\
\text { Systems; Software } \\
\text { Engineering, etc.); }\end{array}$ & Automotive systems \\
\hline $\begin{array}{l}\text { Source } \\
\text { Model(s) }\end{array}$ & $\begin{array}{l}\text { citing models } \\
\text { and/or standards } \\
\text { on which it is } \\
\text { based }\end{array}$ & ISO/IEC 15504 \\
\hline \multirow[t]{2}{*}{$\begin{array}{l}\text { Capability } \\
\text { dimension }\end{array}$} & $\begin{array}{l}\text { Identifying the } \\
\text { structural } \\
\text { elements used in } \\
\text { the definition of } \\
\text { the capability } \\
\text { dimension }\end{array}$ & $\begin{array}{l}\text { Process Assessment Model } \\
\text { (Process Atributes, Assessment } \\
\text { Indicators: Process Capability } \\
\text { Indicators (Generic Practice) and } \\
\text { Process Performance Indicators } \\
\text { (Base Practice, Work Product)) }\end{array}$ \\
\hline & $\begin{array}{l}\text { Identifying the } \\
\text { capability levels } \\
\text { and descriptors }\end{array}$ & $\begin{array}{l}\text { 0. Incomplete Process } \\
\text { 1. Performed Process } \\
\text { 2. Managed Process } \\
\text { 3. Established Process } \\
\text { 4. Predictable Process } \\
\text { 5. Optimizing Process }\end{array}$ \\
\hline \multirow[t]{2}{*}{$\begin{array}{l}\text { Maturity } \\
\text { dimension }\end{array}$} & $\begin{array}{l}\text { Identifying the } \\
\text { structural } \\
\text { elements used in } \\
\text { the definition of } \\
\text { the maturity } \\
\text { dimension }\end{array}$ & - \\
\hline & $\begin{array}{l}\text { Identifying the } \\
\text { maturity levels } \\
\text { and descriptors }\end{array}$ & - \\
\hline \multirow[t]{3}{*}{$\begin{array}{l}\text { Process } \\
\text { dimension }\end{array}$} & $\begin{array}{l}\text { Identifying the } \\
\text { structural } \\
\text { elements used in } \\
\text { the definition of } \\
\text { the process } \\
\text { dimension }\end{array}$ & $\begin{array}{l}\text { PRM (Process Groups, Process } \\
\text { ID, Process Name, Process } \\
\text { Purpose, Process Outcomes and } \\
\text { Process Notes) + PAM (Base } \\
\text { Practices, Work Products and } \\
\text { Work Product's Characteristics) }\end{array}$ \\
\hline & $\begin{array}{l}\text { Identifying } \\
\text { process } \\
\text { categories/groups }\end{array}$ & $\begin{array}{lrr}\text { Acquisition Process } & \text { Group } \\
\text { (ACQ), Supply Process } & \text { Group } \\
\text { (SPL), Engineering } & \text { Process } \\
\text { Group } & \text { (ENG), Supporting } \\
\text { Process } & \text { Group } & \text { (SUP), } \\
\text { Management Process } & \text { Group } \\
\text { (MAN), Process Improvement } \\
\text { Process Group (PIM), Reuse } \\
\text { Process Group (REU). }\end{array}$ \\
\hline & $\begin{array}{l}\text { Identifying the } \\
\text { processes }\end{array}$ & $\begin{array}{l}\text { ACQ.3 Contract agreement } \\
\text { ACQ.4 Supplier monitoring }\end{array}$ \\
\hline
\end{tabular}

\begin{tabular}{|l|l|l|l|}
\hline & $\begin{array}{l}\text { (acronym and } \\
\text { process name })\end{array}$ & {$[\ldots]$} & \\
& & SPL.1 Supplier tendering \\
& & SPL.2 Product release \\
& & ENG.1 Requirements elicitation \\
& & ENG.2 System requirements \\
& & analysis & \\
& & ENG.3 System architecture \\
& design & \\
\hline Further \\
dimension(s) & $\begin{array}{l}\text { Identifying other } \\
\text { possible } \\
\text { dimensions, if any }\end{array}$ & & \\
& & & \\
\hline
\end{tabular}

The definition of such a set of metadata enables a more consistent description of SPCMMs and facilitates the possibility of a central community repository. Such a repository enables new models to be added by their authors. Therefore, creating a living repository of MCMs that will grow over time through the inclusion of new valuable MCMs as they appear 'on the scene'.

Another advantage of dealing only with metadata instead of the models themselves is that there are no issues concerning the attribution of authorship and usage licensing [17]. In an open digital repository, clear authorship attribution for the contents is a key prerequisite for obtaining ready-to-cooperate participants that aspire to build a reputation by writing quality content. Therefore, copyright and licensing must be easily identifiable in order to clearly define the limits of use and reuse in each case.

\section{Implementation}

We are currently implementing the MCM as a web-based repository. The system is being implemented in Java 5.0 on a Web platform, hosted on a Tomcat 6.0 application server (http://tomcat.apache.org/). The database currently in use is MySQL Community Server 5.5 (http://www.mysql.com/downloads/mysq1/).

Figures 2 and 3 provide a first demonstration of the interface design of the search page and the visualization of search results.

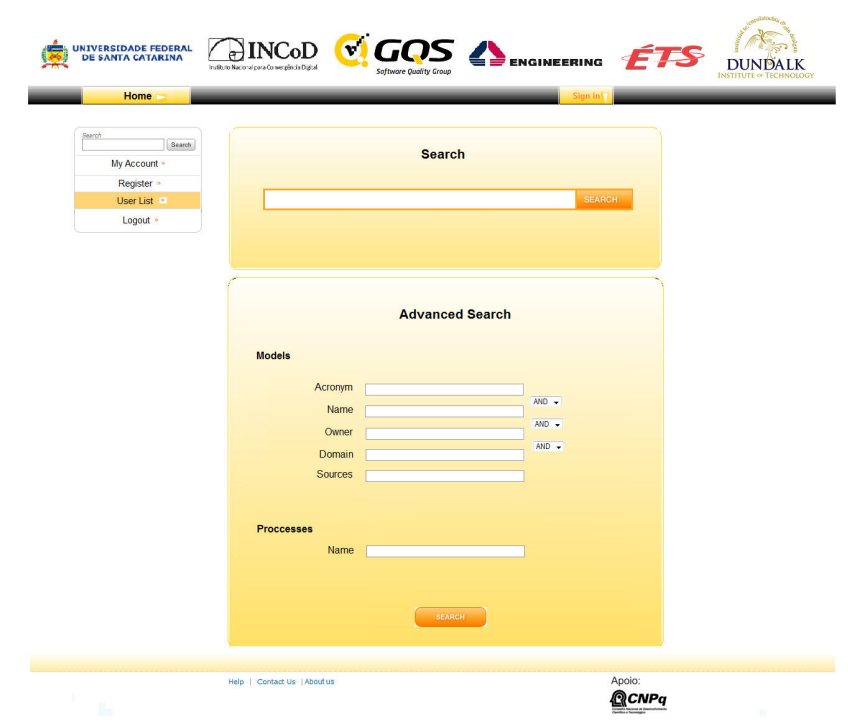

Figure 2 - MCM: search interface 

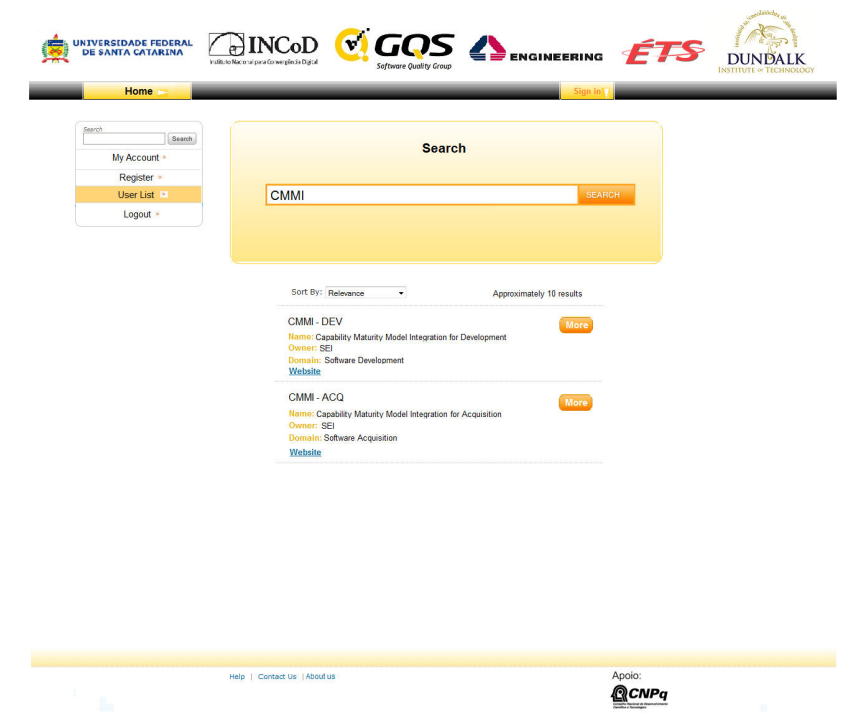

Figure 3 - MCM: Visualization of search results (example)

\section{NEXT STEPS}

Currently we are concluding the implementation of a first version of the repository and planning its evaluation through an expert panel in June 2011. For the evaluation, we will seed initial information on $52 \mathrm{MCMs}$ based on a systematic literature review [18] and invite MCM authors and researchers to use the repository in trial runs intending to evaluate the repositories' utility and usability (including effectiveness, efficiency and user satisfaction). This will be performed through an Expert Panel [20] which is going to take place after the repository be turned public available. We intend to make the MCM repository public available in August 2011 as an important contribution supporting the development of MCMs. Future research planned also include the enhancement of search capabilities in terms of semantic searches as well as graphic presentation alternatives of the information on the MCMs.

\section{ACKNOWLEDGMENTS}

This work was supported by the CNPq (Conselho Nacional de Desenvolvimento Científico e Tecnológico - www.cnpq.br), an entity of the Brazilian government focused on scientific and technological development. The Medi SPICE part of this research is supported by the Science Foundation Ireland (SFI) Stokes Lectureship Programme, grant number 07/SK/I1299, the SFI Principal Investigator Programme, grant number 08/IN.1/I2030 and supported in part by Lero - the Irish Software Engineering Research Centre (http://www.lero.ie).

\section{REFERENCES}

[1] Salviano, C.F., Figueiredo A. 2008. Unified Basic Concepts for Process Capability Models. International Conference on Software Engineering and Knowledge Engineering, San Francisco/USA.

[2] CMMI Product Team. 2010. CMMI for Development, Version 1.3. Technical Report CMU/SEI-2010-TR-033. Carnegie Mellon University/Software Engineering Institute, Pittsburgh.
[3] ISO/IEC - International Organization for Standardization and International Electrotechnical Commission (IEC), ISO/IEC 15504: Information Technology Process Assessment - Part 1 to 5. 2005.ISO/IEC International Standard.

[4] OGC. IT Infrastructure Library (ITIL) v3, 2007.

[5] M, J. re. 2006. The Road Map to Software Engineering: A Standards-Based Guide. Wiley-IEEE Computer Society Press.

[6] Gresse Von Wangenheim, C., Hauck, J.C.R., Zoucas, A., Salviano C., McCaffery F., Shull F. (July/August) 2010. Creating Software Process Capability/Maturity Models. IEEE Software, vol. 27 no. 4, pages 92 -94.

[7] Copeland, L. 2003. The Maturity Maturity Model (M3). Guidelines for Improving the Maturity Process. StickyMinds=

www.stickyminds.com/sitewide.asp?Function=WEEKLYCO LUMN\&ObjectId $=6653$

[8] Magee, S. and Thiele, D. 2004. Engineering Process Standards: State of the Art and Challenges," IEEE IT Pro, vol. 6 , no. $5,38-44$

[9] A. Cass et al. 2004. SPICE for SPACE Trials, Risk Analysis, and Process Improvement. Software Process: Improvement and Practice, vol. 9, no. 1, pp. 13-21.

[10] Automotive SIG. Automotive SPICE - Process Assessment Model. (May 2007) [Online] = http://www.itq.ch/pdf/AutomotiveSPICE_PAM_v23.pdf

[11] McCaffery, F., Dorling, A. 2010. Medi SPICE Development, Software Process Maintenance and Evolution: Improvement and Practice Journal. Volume 22 Issue 4, 255 - 268.

[12] Ibrahim, L. 2008. Improving Process Capability Across Your Enterprise, 4th World Congress on Software Quality (4WCSQ), Bethesda/USA.

[13] Hauck, J.C.R., Gresse Von Wangenheim, C., McCaffery, F.; Buglione, L. 2011. Proposing an ISO/IEC 15504-2 Compliant Method for Process Capability/Maturity Models Customization. Proceedings of the 12th International Conference on Product Focused Software Development and Process Improvement (PROFES 2011), Italy, 20-22.

[14] Maier, R. 2007. Knowledge Management Systems: Information And Communication Technologies for Knowledge Management. 3rd edition, Berlin: Springer.

[15] Wenger, E. 1998. Communities of Practice: Learning, Meaning, and Identity. Cambridge: Cambridge University Press.

[16] ISO/IE JTC1 SC 32 WG2. Metadata Standards= http://metadata-standards.org/.

[17] Monge, S., Ovelar, R., Azpeiti, I. 2008. Repository 2.0: Social Dynamics to Support Community Building in Learning Object Repositories, Interdisciplinary Journal of Elearning and Learning Objects, Vol.4. IJKLO = http://ijklo.org/Volume4/IJELLOv4p191-204Monge.pdf

[18] Gresse von Wangenheim C., Hauck J.C.R., Salviano C.F., Von Wangenheim A. 2010. Systematic Literature Review of Software Process Capability/Maturity Models. Proceedings of the 10th International Conference on Software Process. Improvement And Capability dEtermination (SPICE 2010), Italy.

[19] WIBAS. CMMI Browser= http://www.cmmi.de/\#el=CMMI/0/HEAD/folder/folder.CM MI

[20] Beecham, S., Hall, T., Britton, C., Cottee, M., Rainer, A. 2005. Using an Expert Panel to Validate a Requirements Process Improvement Model. The Journal of Systems and Software, v. 76. 